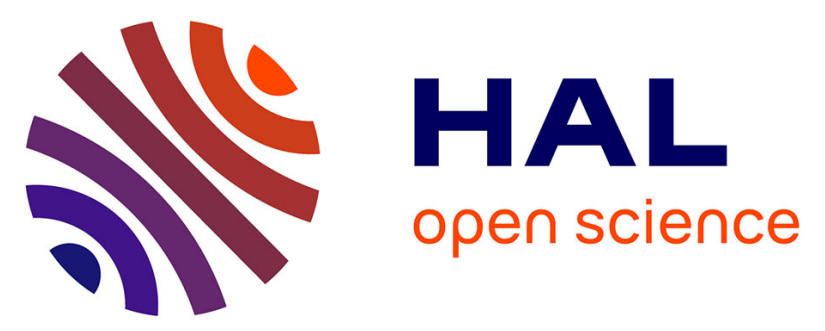

\title{
Tracking shoreline erosion of "at risk" coastal archaeology: the example of ancient Siraf (Iran, Persian Gulf)
}

Majid Pourkerman, Nick Marriner, Christophe Morhange, Morteza Djamali, Sedighe Amjadi, Hamid Lahijani, Abdolmajid Naderi Beni, Matteo Vacchi, Hossein Tofighian, Majid Shah-Hoesseini

\section{To cite this version:}

Majid Pourkerman, Nick Marriner, Christophe Morhange, Morteza Djamali, Sedighe Amjadi, et al.. Tracking shoreline erosion of "at risk" coastal archaeology: the example of ancient Siraf (Iran, Persian Gulf). Applied Geography, 2018, 101, pp.45-55. 10.1016/j.apgeog.2018.10.008 . hal-02081222

\section{HAL Id: hal-02081222 \\ https://hal-amu.archives-ouvertes.fr/hal-02081222}

Submitted on 27 Mar 2019

HAL is a multi-disciplinary open access archive for the deposit and dissemination of scientific research documents, whether they are published or not. The documents may come from teaching and research institutions in France or abroad, or from public or private research centers.
L'archive ouverte pluridisciplinaire HAL, est destinée au dépôt et à la diffusion de documents scientifiques de niveau recherche, publiés ou non, émanant des établissements d'enseignement et de recherche français ou étrangers, des laboratoires publics ou privés. 


\title{
Tracking shoreline erosion of "at risk" coastal archaeology: the example of ancient Siraf (Iran, Persian Gulf)
}

\author{
Majid Pourkerman $^{\mathrm{a}, \mathrm{e}}$, Nick Marriner ${ }^{\mathrm{b}, *}$, Christophe Morhange ${ }^{\mathrm{a}}$, Morteza Djamali ${ }^{\mathrm{c}}$, \\ Sedighe Amjadi $^{\mathrm{d}}{ }^{\mathrm{e}}$, Hamid Lahijani ${ }^{\mathrm{e}}$, Abdolmajid Naderi Beni ${ }^{\mathrm{e}}$, Matteo Vacchi ${ }^{\mathrm{f}}$, \\ Hossein Tofighian ${ }^{\text {, }}$, Majid Shah-Hoesseini ${ }^{\text {h }}$ \\ ${ }^{a}$ CEREGE - UM 34 Aix-Marseille Université, CNRS, IRD, Collège de France, INRA, BP80, 13545, Aix-en-Provence CEDEX 04, France \\ ${ }^{\mathrm{b}}$ CNRS, Laboratoire Chrono-Environnement UMR 6249, MSHE Ledoux, USR 3124, Université de Bourgogne-Franche-Comté, UFR ST, 16 Route de Gray, 25030 , \\ Besançon, France \\ ${ }^{\mathrm{c}}$ Institut Méditerranéen de Biodiversité et d'Ecologie, IMBE-UMR CNRS 7263/IRD/Aix-Marseille Université, Europôle de l'Arbois BP 80, BP 80, 13545, Aix-en-Provence, \\ France \\ ${ }^{\mathrm{d}}$ Department of Geology, Ferdowsi University, Mashhad, Iran \\ ${ }^{\mathrm{e}}$ Iranian National Institute for Oceanography and Atmospheric Science (INIOAS), Tehran, Iran \\ ${ }^{\mathrm{f}}$ Geography, College of Life and Environmental Sciences, University of Exeter, Exeter, EX4 4RJ, UK \\ ${ }^{g}$ Iranian Centre of Archaeological Science, Tehran, Iran \\ ${ }^{\mathrm{h}}$ Department of Geomorphology, Kharazmi University, Tehran, Iran
}

A R T I C L E I N F O

Keywords:

GIS

Geography

Remote sensing

Waterfront archaeology

Coasts

Erosion

Heritage management

Protection

Iran

Persian Gulf

\begin{abstract}
A B S T R A C T
Successful heritage management requires a robust comprehension of the threats facing archaeological sites, at both current and future timescales. Siraf, on the Persian Gulf of Iran, is a site of national and international importance whose history stretches back to the Sassanid period (224-652 AD). In the present context of global change (drought and relative sea-level rise) and anthropogenic impacts (coastal artificialization and reduced sediment supply), the city's waterfront archaeology is undergoing significant erosion. Nonetheless, at present, the processes leading to the loss of Siraf's in situ archaeological remains are still poorly understood, including the rates, timing and drivers of coastal erosion. Here we use Landsat images to monitor shoreline changes along the Siraf coastline between 1973 and 2016. We spatially quantify the causes and impacts of surface changes along 244 transects. The results demonstrate that coastal erosion is responsible for widespread and archaeologically significant damage, with $48 \%$ of the studied transects showing erosion during the period 1973-2016. We elucidate significant temporal variations in the data and, most notably, demonstrate that continued drought since the early 2000s has impacted upon sediment supply to coastal areas, severely accentuating erosion. For instance, between 2003 and 2016, 70\% of transects recorded shoreline retreat with worrying implications for the waterfront archaeology of Siraf. These quantitative results provide invaluable spatial information regarding the causes and impacts of erosion upon Siraf's waterfront heritage, in addition to furnishing a template for the protection of the city's internationally important cultural heritage.
\end{abstract}

\section{Introduction}

Probing the rates, timing and drivers of erosion on and around archaeological sites is key to developing effective heritage management strategies (Ahmad, 2006) to ensure the long-term survival of threatened remains (Dawson, 2005; Dromgoole, 2006; Mourtzas \& Marinos, 1994). Damage to archaeological sites can derive from a plethora of both natural (Robinson, Alexander, Jackson, McCabe, \& Crass, 2010; Stewart, 1999) and anthropogenic (Wilkinson, Tyler, Davidson, \&
Grieve, 2006) factors, each of which may operate at different temporal and spatial timescales. In the current context of global change, archaeological sites in coastal areas are particularly vulnerable and at risk from erosion (Erlandson, 2008, 2012), essentially underpinned by three cumulative factors: (1) the dynamic geomorphological character of coastal areas; (2) relative sea-level rise (e.g. Brunel \& Sabatier, 2009; Ford \& Kench, 2015); and (3) climate and human-induced reductions in sediment supply to coastal areas (Anthony, Marriner, \& Morhange, 2014; El Banna \& Frihy, 2009; Syvitski, Vörösmaty, Kettner, \& Green,

\footnotetext{
* Corresponding author.

E-mail address: nick.marriner@univ-fcomte.fr (N. Marriner).
} 
2005). Quantifying the drivers and rates of change of "at risk" coastal sites, using integrated geographical, geoarchaeological and geomorphological approaches, is therefore critical in developing informed approaches to the management and effective conservation of archaeological remains (Andreou et al., 2017; Franco, 1996; Marriner \& Morhange, 2005).

Quantitative techniques, based on historical documents and satellite images, have been demonstrated to be powerful tools in quantifying shoreline changes at annual to decadal timescales (García-Rubio, Huntley, \& Russell, 2015; Pardo-Pascual, Almonacid-Caballer, Ruiz, \& Palomar-Vázquez, 2012). For instance, Landsat sensor series (MSS, TM, ETM + and OLI) have provided continuous and widely democratized data since 1972, and have become one of the most common data sources employed to map and monitor shoreline changes (Miller et al., 2011). Satellite imagery techniques have also been used in archaeological reconnaissance (Beck, Philip, Abdulkarim, \& Donoghue, 2007; Deroin, Téreygeol, \& Heckes, 2011; Lasaponara \& Masini, 2011). The infrared and visible bands of the Landsat sensors are particularly useful in differentiating between land surface and water (Yamazaki, Trigg, \& Ikeshima, 2015), and can therefore aid in quantitatively probing the spatial and temporal dimensions of recent shoreline change. These approaches are extremely valuable for assessing longer-term patterns of change around archaeological sites in coastal areas.

\subsection{Research aims and archaeological context}

This study uses a series of Landsat satellite images from 1973 to 2016, and various statistical techniques (Net Shoreline Movement [NSM], End Point Rate [EPR], Last Median of Square [LMS]), to monitor 44 years of coastal erosion along the Siraf coastline. Our analysis helps to identify "at risk" archaeological zones, findings that were corroborated during recent field surveys by the authors. The erosion of Siraf's archaeological remains has been highlighted by a number of recent publications (e.g. Khakzad, Trakadas, Harpster, \& Wittig, 2015a) but quantitative estimates to assess the spatial and temporal dimensions of these changes have been hitherto lacking. As an ancient port city, Siraf possesses extensive waterfront archaeology, where geomorphic processes are particularly active and capable of exacerbating this erosion potential. Coupled with global change and human impacts, the combined consequences of these factors mean that Siraf's archaeological remains are being subjected to high rates of decay and destruction. The deterioration of Siraf's archaeological remains is compounded by the fact that the site has yet to be registered on the list of national heritage sites of Iran, although it features on the United Nations Educational, Scientific and Cultural Organization (UNESCO) World Heritage Tentative List since 2007. Addressing these challenges is imperative to the effective present and future preservation of the site's archaeological heritage (Khakzad, Pieters, \& Van Balen, 2015b).

During the Sassanian period (224-652 AD), imported objects indicate that trade relations had developed between Siraf and the Arabian Sea region as far as the Makran and Sind coasts near the regions of Karachi and Gujarat (Ricks, 1970; Whitehouse, 2009; Whitehouse \& Williamson, 1973). By the 6th century AD, contacts extended west to at least Aden and south along the Indian coast and on to Sri Lanka (Whitehouse, 2009). Chinese ceramics are first attested before c. 750-775 AD (Pashazanous, Montazer Zohouri, \& Ahmadi, 2014; Whitehouse, 2009). There is abundant textual and archaeological evidence pertaining to the medieval period at Siraf. The site appears to have enjoyed its greatest period of prosperity during the 9th and 10th centuries AD. The large Congregational Mosque, constructed over the Sassanian fort, was completed in 825 AD (Whitehouse, 1980). Remains of the medieval city of Siraf are extensive, with several mosques, bazaars, merchants' houses, a fortification system, cisterns and aqueducts (Whitehouse, 2009; Wilkinson, 1974). The wealth and prosperity of medieval Siraf is described by numerous historians from this period. They portray a wide trade network spanning the Red Sea to the East
African coast, India and the Far East. After the mid-11th century AD, the city gradually lost its importance and when $\mathrm{Ya}^{-} \mathrm{qu}^{-} \mathrm{t}$ visited Siraf in the early 13th century, he describes a settlement of just a few residents (Ya- ${ }^{-}{ }^{-}$t, 1955-57).

In this paper we probe the when, where and why of coastal erosion along the coast of Siraf and assess it within the context of the city's cultural heritage. The aims of the present study are:

(1) to quantitatively assess the erosion rates along Siraf's waterfront, between 1973 and 2016;

(2) to map these changes using different chronological windows, in order to understand the spatial dimensions and implications of this erosion in relation to the archaeological remains and other sensitive urban areas;

(3) to probe the causes of coastal change; and

(4) to propose maps of "at risk" waterfront remains for local, national and international planners, heritage managers and other stakeholders.

\subsection{Study area}

The study area is located at $52^{\circ} 18^{\prime} 30^{\prime \prime}$ to $52^{\circ} 21^{\prime} 30^{\prime \prime} \mathrm{E}$ and $27^{\circ} 39^{\prime}$ $00^{\prime \prime}$ to $27^{\circ} 41^{\prime} 00^{\prime \prime}$. Siraf occupies a narrow coastal plain, around $0.5-1 \mathrm{~km}$ wide, delimited by the foothills of the Zagros Mountain range in the north and ephemeral watercourses to the east and west. Siraf is one of the most important ancient ports of the Persian Gulf (Fig. 1), with a documented history stretching back to the Sassanian period, when Shapur II established a coastal fort at the site in the 4th century AD. Archaeological understanding of Siraf is based largely on the work of Whitehouse and colleagues who extensively excavated the site during the 1960s and early 1970s. More recently, the waterfront archaeology of Siraf has been investigated by Khakzad et al. (2015a).

\section{Methods}

\subsection{Data sources}

To quantify shoreline changes along the Siraf coastline, we used multi-temporal Landsat data, Multispectral Scanner (MSS), Thematic Mapper (TM), Enhanced Thematic Mapper (ETM+) and Operational Land Imager (OLI), for the period 1973-2016. The Landsat satellites have overpass frequencies of 16 days with an equatorial crossing time at 10:00 a.m. The data properties are presented in Table 1. We downloaded Level 1T Landsat images from USGS EarthExplorer (http:// earthexplorer.usgs.gov). The Top of Atmospheric (TOA) was calculated from the DN (Digital Number) for every band (Equation (1)).

$\mathrm{L}_{\mathrm{TOA}}=\mathrm{M}_{\mathrm{L}} \times \mathrm{DN}+\mathrm{A}_{\mathrm{L}}$

The $M_{L}$ (gain) and $A_{L}$ (offset) values were given in the metadata files. TOA reflectance was calculated by normalizing $\mathrm{L}_{\mathrm{TOA}}$ to the band average solar irradiance (Equation (2)):

$\rho_{\mathrm{TOA}}=\frac{\pi \cdot \mathrm{L}_{\mathrm{TOA}} \cdot \mathrm{d}^{2}}{\mathrm{~F} 0 \cdot \cos \theta_{0}}$

Where $d$ is the earth-sun distance, $\theta_{0}$ the sun zenith angle and F0 solar irradiance for the band average. $\rho_{\mathrm{TOA}}$ denotes the sun reflectance observed by the sensor. In this study, we used simplified $\rho_{\mathrm{TOA}}$ for the atmospheric correction (Vanhellemont and Ruddick, 2014) (Equation (3)).

$\rho_{T O A}=\rho_{r}+\rho_{a}+t_{0} t_{v} \rho_{w}$

where $\rho_{\mathrm{r}}$ and $\rho_{\mathrm{a}}$ are reflectance values resulting from aerosols and Rayleigh scattering and $t_{0}$ is diffuse transmittance for the sun-sea and sea-sensor $\left(t_{v}\right) \cdot t_{0}$ and $t_{v}$ paths are calculated by substituting $\theta$ with $\theta_{0}$ and $\theta_{\mathrm{v}}$ (Equation (4)): 

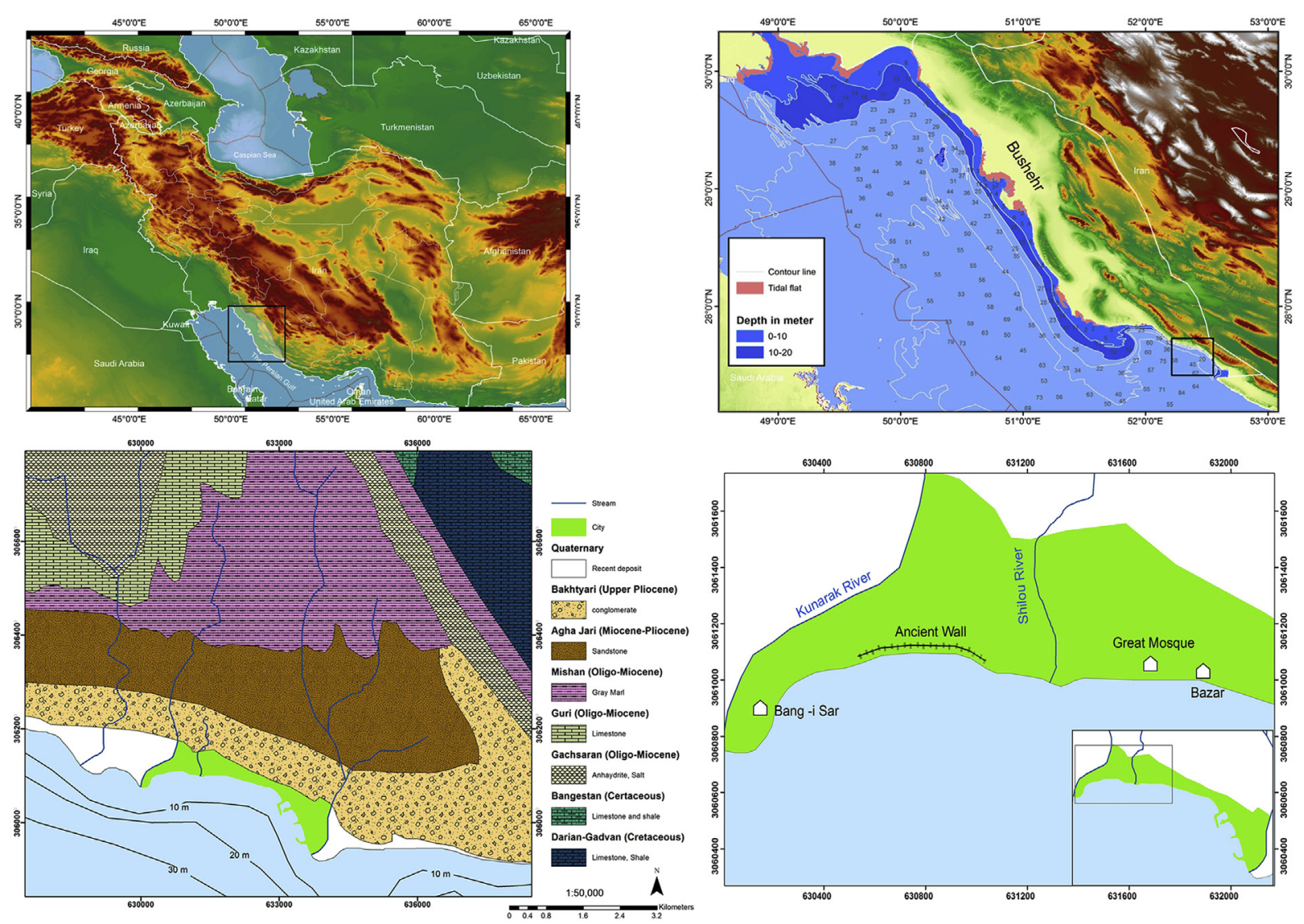

Fig. 1. Location maps of Siraf in the Persian Gulf and local geomorphological context.

Table 1

Data sources used in this paper (U.S. Geological Survey, 2014).

\begin{tabular}{|c|c|c|c|c|c|c|}
\hline Sensor & Time $($ GTM + 3:30) & Date of acquisition & Path/Row & Bands & Resolution (m) & Wavelength $(\mathrm{nm})$ \\
\hline \multirow{2}{*}{ MMS } & & & & Band 5 - Red & 60 & $0.6-0.7$ \\
\hline & & & & Band 6 - NIR 1 & 60 & $0.7-0.8$ \\
\hline \multirow[t]{5}{*}{ TM } & $6: 25: 33$ & 13-Oct-87 & $162 / 41$ & Band 1 - Blue & 30 & $0.45-0.52$ \\
\hline & & & & Band 2 - Green & 30 & $0.52-0.60$ \\
\hline & & & & Band 3 - Red & 30 & $0.63-0.69$ \\
\hline & & & & Band 4 - NIR & 30 & $0.76-0.90$ \\
\hline & & & & Band 7 - SWIR 1 & 30 & $2.08-2.35$ \\
\hline \multirow[t]{6}{*}{ ETM + (SLC on $)$} & $6: 46: 53$ & 8-Apr-03 & $162 / 41$ & Band 1 - Blue & 30 & $0.45-0.515$ \\
\hline & & & & Band 2 - Green & 30 & $0.525-0.605$ \\
\hline & & & & Band 3 - Red & 30 & $0.63-0.69$ \\
\hline & & & & Band 4 - NIR & 30 & $0.75-0.90$ \\
\hline & & & & Band 5 - SWIR 1 & 30 & $1.55-1.75$ \\
\hline & & & & Band 6 - TIR & 60 & $10.40-12.5$ \\
\hline \multirow{6}{*}{ OLI } & & & & Band 4 - Red & 30 & $0.630-0.680$ \\
\hline & & & & Band 5 - NIR & 30 & $0.845-0.885$ \\
\hline & & & & Band 6 - SWIR 1 & 30 & $1.560-1.660$ \\
\hline & & & & Band 7 - SWIR 2 & 30 & $2.100-2.300$ \\
\hline & & & & Band 8 - Panchromatic & 15 & $0.500-0.680$ \\
\hline & & & & Band 9 - Cirrus & 30 & $1.360-1.390$ \\
\hline
\end{tabular}




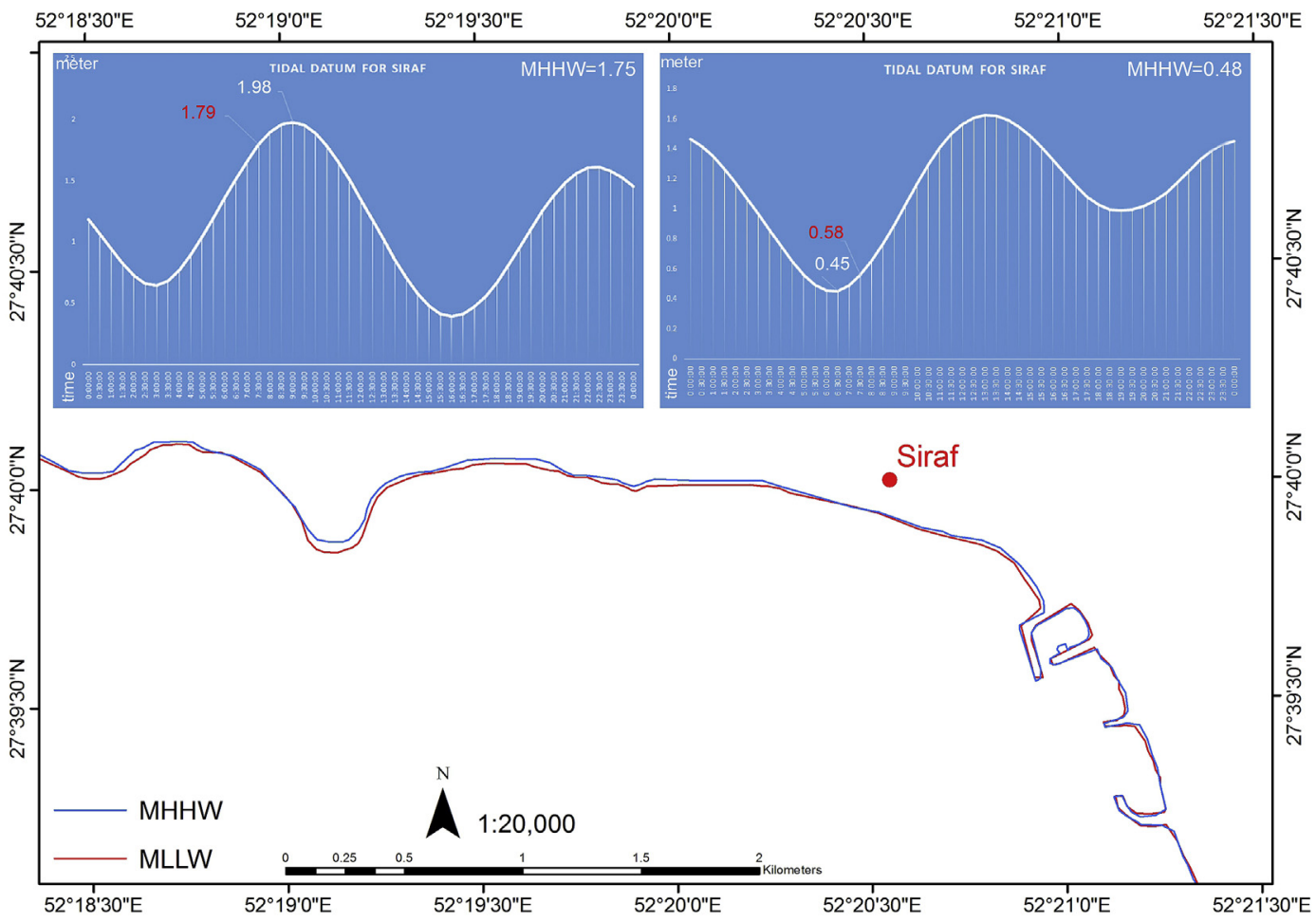

Fig. 2. Tidal information for Bandar-e Taheri (Siraf), obtained from the NCC database (http://iranhydrography.ncc.org.ir).

$t=\exp \left[-\left(\frac{\tau_{r}}{2}+\tau_{o z}\right) / \cos \theta\right.$

where $\tau_{r}$ and $\tau_{o z}$ are the average bands of Rayleigh and Ozone optical thickness for a standard atmosphere.

Aerosol reflectance was estimated using a method outlined by Ruddick, Anis, \& Thompson, 2000. The images were georeferenced using 1:100,000 topographic maps from the National Cartographic Center (NCC) with a Root Mean Square Error (RMSE) of between 0.01 and 0.05 pixels.

\subsection{Shoreline detection and digitization}

The determination of reliable shoreline positions using remote sensing (RS) techniques depends on various factors such as differences in the tidal range and meteorological conditions during image acquisition (Singh, 2002; Ryu, Won, \& Min, 2002; Boak and Turner, 2005). The tides in the study area are semidiurnal and Mean Higher High Water (MHHW) is $1.7 \mathrm{~m}$. For the purposes of this investigation, we selected images acquired during calm sea conditions and in which the high-water line from the last high tide was clearly visible (Klemas, 2011). The tidal information for Siraf (Bandar-e Taheri) was obtained from the NCC database (http://iranhydrography.ncc.org.ir; Fig. 2). The data were available for the years 2006-2016 and provide useful information for the sea-level position during MHHW at Siraf on Landsat OLI images. We used these data as a baseline to choose other images according to the sea-level position on the variable beach morphology. This approach helps to dramatically reduce the tide-effected width during shoreline mapping.

The Normalized Water Difference Index (NWDI) is a suitable method to extract shoreline positions from MSS images because it has a limited wavelength, from 0.5 to $1.1 \mathrm{~nm}$. The Near Infrared (NIR) band of the MSS images helps to delineate the water-saturated zone in the vicinity of the land-water boundary (Tulbure, Broich, Stehman, \& Kommareddy, 2016). Automated Water Extraction Index (AWEI) were employed to detect shoreline positions from the TM, ETM + and OLI, which supported wider spectral wavelength (Table 2).

A threshold value was applied to the NWDI and AWEI images in order to differentiate between the surface water/non-surface water zone along the Siraf coastline (Fig. 3). The selected pixels representing the shoreline position were converted into vector layers using ArcGIS ver. 10.3 .

\subsection{Littoral cells and transects}

Field observations and existing information from coastal surveys undertaken by the hydrographic department of the NCC (2012) were used to define four coastal cells (zones 1 to 4; see Fig. 3). The beaches of zones 1,2 and 4 are gravel dominated whereas zone 3 essentially comprises sand. The littoral cells have been subdivided into perpendicular transects against the baseline. The baseline was defined as the 1973 shoreline. Using the Digital Shoreline Analysis System (DASA ver. 4.3), shoreline changes were assessed for 244 transects at 50-m intervals. There are 46 transects in zone 1, 64 in zone 2, 87 in zone 3 and 47 in zone 4.

\subsection{Uncertainty and predictability}

Accurately mapping shoreline positions has always been associated

Table 2

Land-water extraction indices.

\begin{tabular}{|c|c|c|}
\hline Index & Equation & Reference \\
\hline Normalized Difference Water Index & NDWI $=($ Green $-\mathrm{NIR}) /($ Green + NIR $)$ & McFeeters, 1996 \\
\hline Automated Water Extraction Index & AWEI $=4 \times($ Green - SWIR 1$)-(0.25 \times$ NIR $+2.75 \times$ SWIR2 $)$ & Feyisa et al., 2014 \\
\hline
\end{tabular}



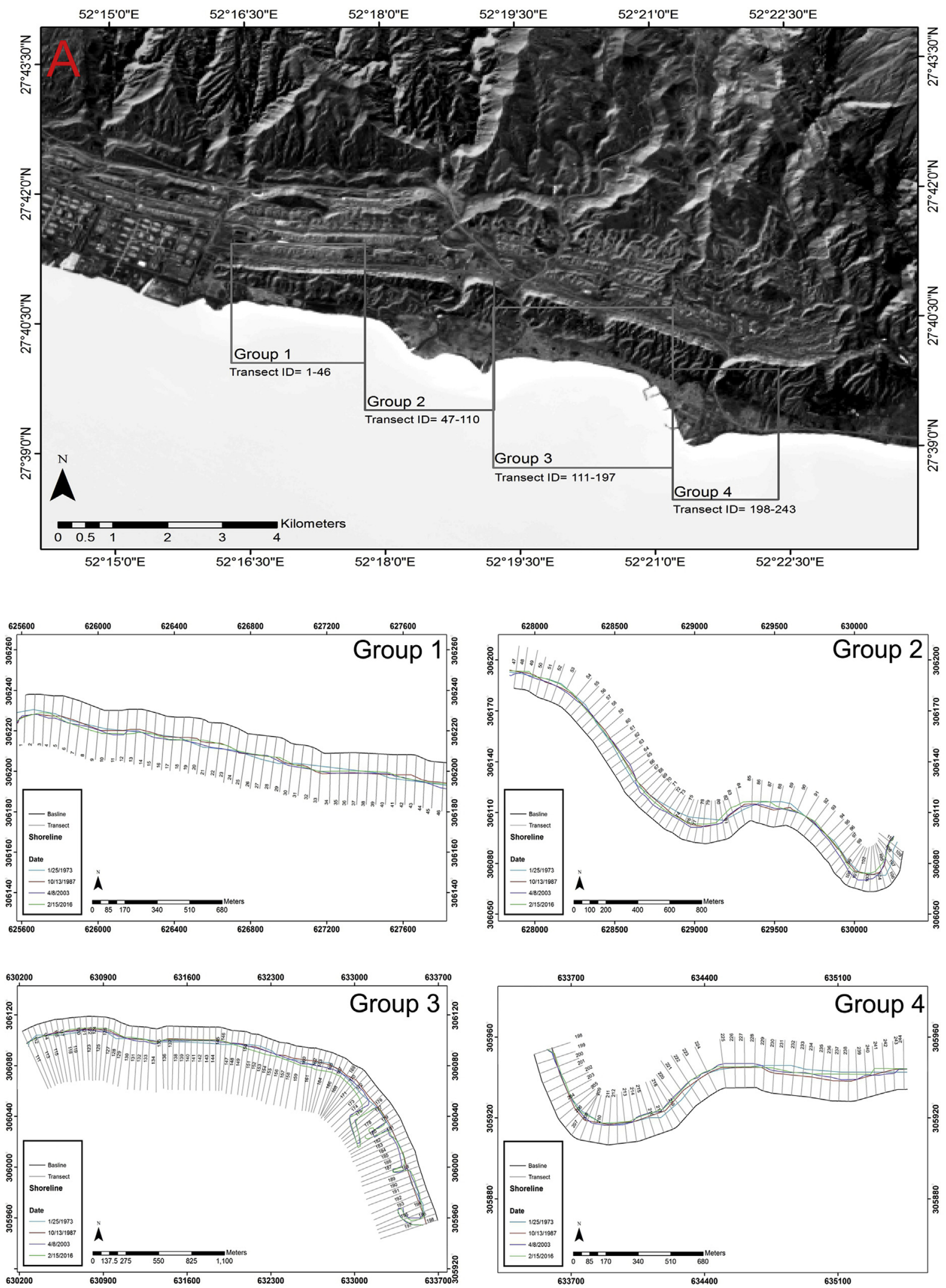

Fig. 3. Position of the 244 transects used in this study. These have been grouped into four zones based on the local littoral cells.

with significant uncertainties, because the shoreline position is constantly influenced by long-shore sediment movements and tides (Appeaning Addo, Walkden, \& Mills, 2008). Typical inventory errors have been estimated by several studies. The shoreline position error was calculated using summation errors, such as satellite data resolution and scale, the topographic map SOI reference used for geo-referencing and digitizing error (Moore, 2000; Morton, Miller, \& Moore, 2004). A separate error was calculated for each shoreline. These error margins were incorporated into all transects. 


\subsection{Shoreline changes and prediction}

Siraf shoreline changes were measured using NSM and EPR methods for the periods 1973-1987, 1987-2003, 2003-2016, 1987-2016 and 1973-2016. For each transect, the distance between the oldest and the most recent shoreline was calculated by NSM (Manca, Pascucci, Deluca, Cossu, \& Andreucci, 2013). The EPR was calculated by dividing shoreline change by time. The EPR unit is meters per year (Equation (5)).

$E P R=\frac{\left(d_{1}-d_{0}\right)}{\left(t_{1}-t_{0}\right)}$

Where $\mathrm{d}$ is the distance in meters between the intersected shorelinetransect and the baseline, and $\mathrm{t}$ indicates time.

The Last Median of Square (LMS) is a rate-of-change statistical method used to determine the rate of shoreline change by fitting least square regression lines to all shoreline intersections for a particular transect. Unlike linear regressions that are based on the mean of the residuals, the LMS uses the median value of the squared residuals to give a best-fit line equation (Rousseeuw \& Leroy, 2005). This method provides more reliable regression estimates and minimizes shoreline prediction errors.

\section{Results and discussion}

Our results manifest temporal and spatial variations in shoreline change rates at Siraf and highlight a number of pressing concerns with regards to the city's waterfront archaeology. For the total period 1973-2016, the study area shows a general trend towards moderate progradation with a mean shoreline advance rate of $0.24 \mathrm{~m} \mathrm{yr}^{-1}$ (Figs. 4 and 5), and minimum and maximum values of $-1.57 \mathrm{~m} \mathrm{yr}^{-1}$ and $7.14 \mathrm{~m} \mathrm{yr}^{-1}$ respectively. For the three intervening periods, we recorded an overall erosional trend between 1973 and 1987 (mean $=-0.11 \mathrm{~m} \mathrm{yr}^{-1}$ ), a progradational trend between 1987 and 2003 (mean $=1.1 \mathrm{~m} \mathrm{yr}^{-1}$ ) and a renewed erosional phase between 2003 and 2016 (mean $=-0.35 \mathrm{~m} \mathrm{yr}^{-1}$; Fig. 6). We focus notably on the period 2003-2016, which is most important in contextualizing the present predicament of Siraf's waterfront remains. As outlined above, during data processing the results were divided into four areas consistent with the local littoral cells, due to the significant spatial differences in both the EPR and NSM results. The EPR and NSM results are discussed below in relation to each of these areas, before the overall trends are considered together as part of a wider discussion of the results.

\subsection{Zone 1}

Zone 1 has the lowest number of transects in our study $(n=46)$. Total change from all geomorphic processes identified within zone 1 resulted in extremely moderate mean shoreline advance of $0.007 \mathrm{~m}$ $\mathrm{yr}^{-1}$ for the total study period of 1973-2016. For the three intercalating time windows, we observed average erosion of $-0.192 \mathrm{~m} \mathrm{yr}^{-1}$ for the period 1973-1986, accretion of $0.6 \mathrm{~m} \mathrm{yr}^{-1}$ for the period $1987-2003$ and average erosion of $-0.478 \mathrm{~m} \mathrm{yr}^{-1}$ between 2003 and 2016. For the period 2003-2016, shoreline retreat was observed along $80 \%$ of the transects in this zone (Fig. 7). Spatially, erosion was distributed throughout the entire length of the zone, and appears to be linked to down-drift reductions in sediment supply from the two local watercourses in zone 2 . The maximum rate of erosion was $-2.03 \mathrm{~m}$ $\mathrm{yr}^{-1}$ along transect 21 .

\subsection{Zone 2}

Zone 2 has a total of 64 transects. Overall, for the 44-year survey period, erosion in zone 2 was $-0.06 \mathrm{~m} \mathrm{yr}^{-1}$. We reconstructed average accretion of $0.078 \mathrm{~m} \mathrm{yr}^{-1}$ and $0.506 \mathrm{~m} \mathrm{yr}^{-1}$ for the periods 1973-1987 and 1987-2003 respectively, consistent with two fluvial systems in this zone that supply sediment. By contrast, the most recent period, 2003-2016, was characterized by a switch to an erosional trend, with average erosion rates of $-0.905 \mathrm{~m} \mathrm{yr}^{-1}$. For this 13-year time window, erosion was particularly pronounced around the mouths of the two fluvial systems in this area, in addition to around the old city walls of Siraf. Between 2003 and 2016, 80\% of the transects recorded shoreline retreat with maximum rates of $-3.19 \mathrm{~m} \mathrm{yr}^{-1}$ in transect 102 .

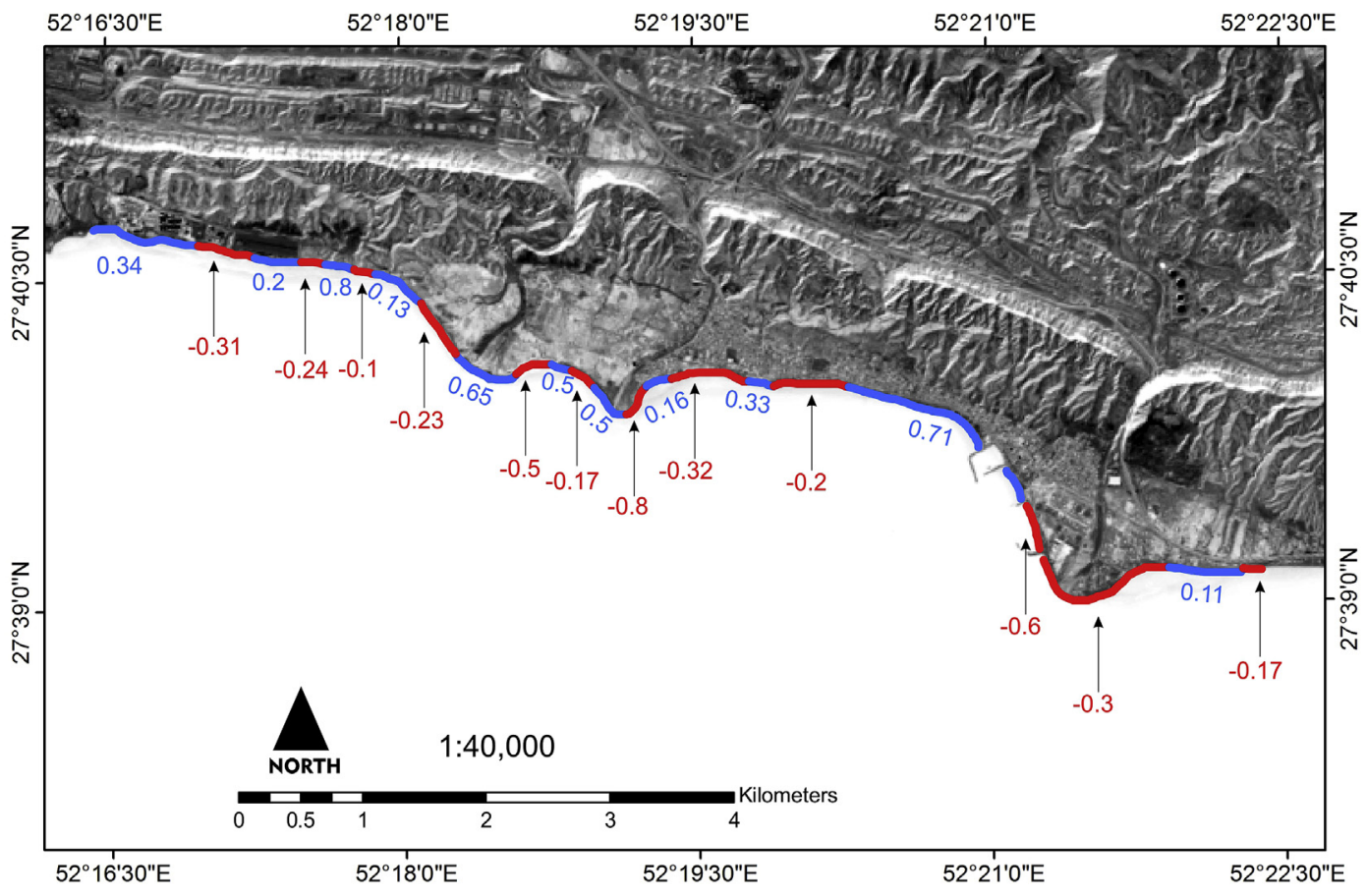

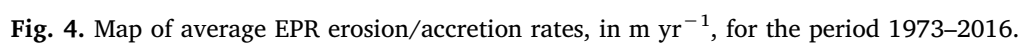




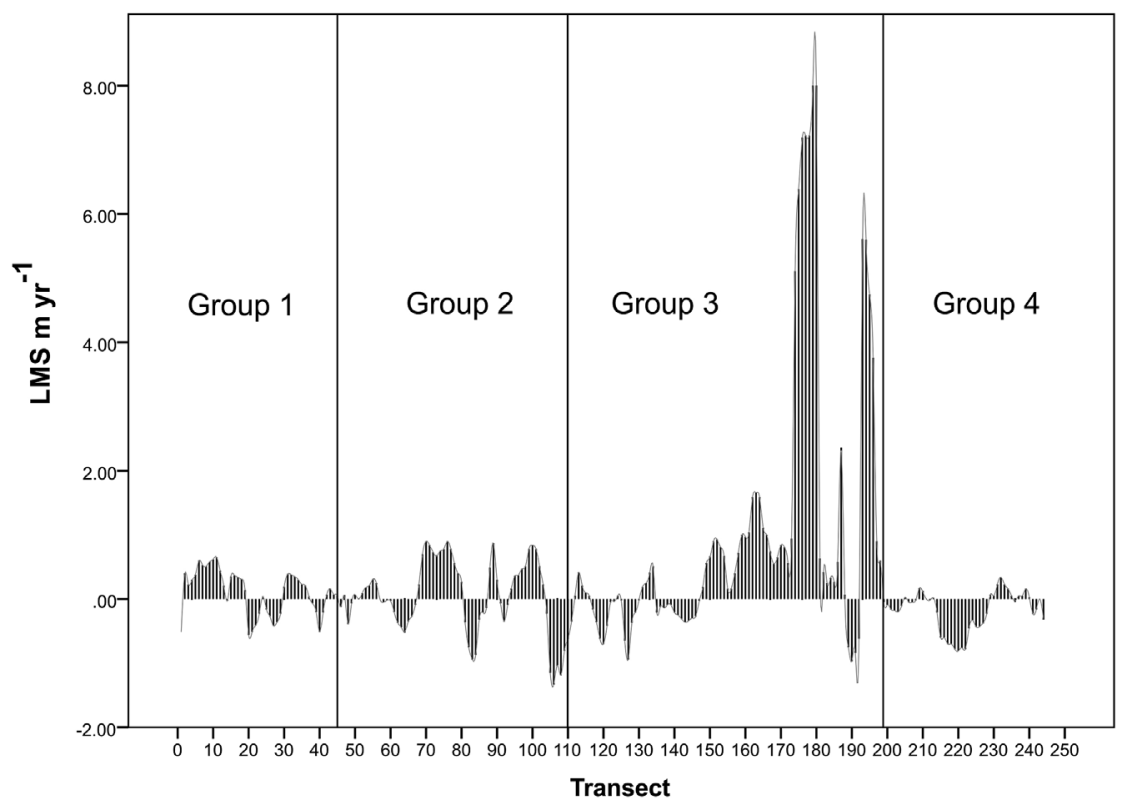

Fig. 5. Histogram of LMS erosion/accretion rates, in $\mathrm{m} \mathrm{yr}^{-1}$ and by transect, for the period 1973-2016.

\subsection{Zone 3}

Zone 3 contains the highest number of transects in our study, with a total of 87. This area is significant because it contains a high density of archaeological vestiges, including, from west to east, Bang-I Sar, the ancient fort wall, the Great Mosque and the Bazaar. The zone records overall accretion for the period 1973-2016 with an average rate of $0.766 \mathrm{~m} \mathrm{yr}^{-1}$. Nonetheless, over the 44 -year period, we observed significant temporal variations in the data. Between 1973 and 1986, 69\% of the transects in this area recorded erosion with a total average rate of $-0.582 \mathrm{~m} \mathrm{yr}^{-1}$ and a maximum rate of $-2.97 \mathrm{~m} \mathrm{yr}^{-1}$ in transect 170 (Figs. 6 and 7). By contrast, the period 1986-2003 was characterized by generalized progradation, notably around Siraf port. During this timeframe, we recorded strong average accretion of $2.539 \mathrm{~m} \mathrm{yr}^{-1}$ for the zone as a whole, with a maximum rate of $19.92 \mathrm{~m} \mathrm{yr}^{-1}$ at transect 179. These highly skewed data are the result of the construction of seawalls to create a coastal resort in 2008. Not only did these structures significantly artificialize zone 3 but they also affected longshore sediment transport to other littoral cells along the Siraf coastline. The structure acts as a sediment bypass and, by longshore processes, transports sediment to the fishing harbour of Siraf. For the period 2003-2016, the overall trend is accretional, with an average rate of $0.174 \mathrm{~m} \mathrm{yr}^{-1}$. Nonetheless, $57 \%$ of the transects show an erosional trend with significant implications for the waterfront archaeology in this area (Fig. 8). In particular, erosion rates $>1 \mathrm{~m} \mathrm{yr}^{-1}$ were recorded at the foot of the sea-facing wall of Siraf's old city, which is disturbing

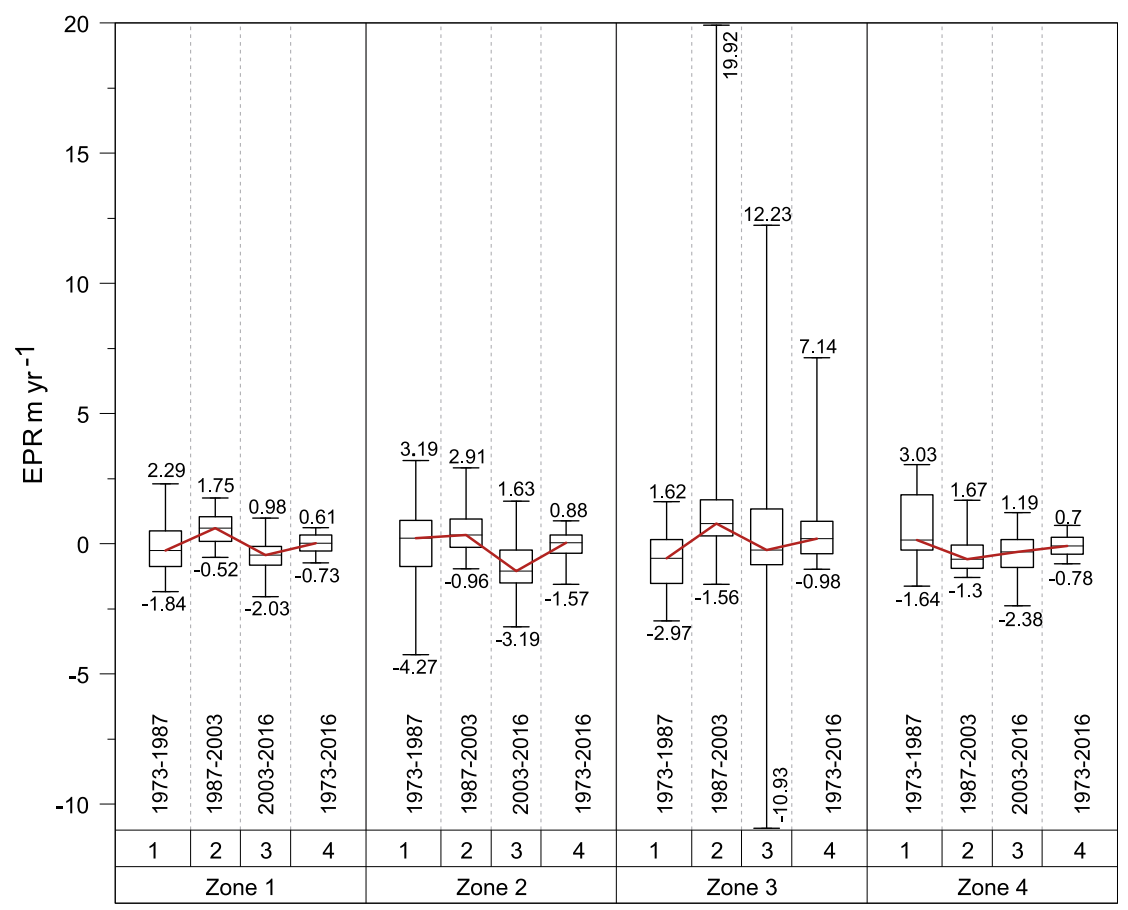

Fig. 6. Boxplots of EPR shoreline changes by zone and for the different time periods (1: 1973-1987; 2: 1987-2003; 3: 2003-2016 and 4: 1987-2016) investigated in this study. 


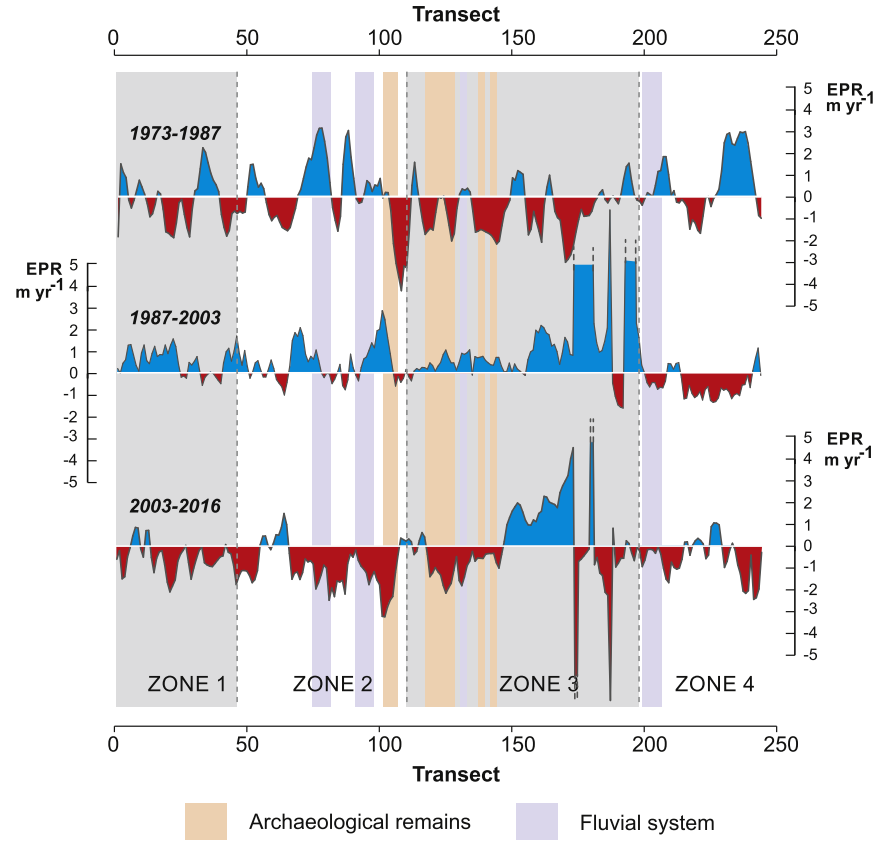

Fig. 7. Histogram of EPR erosion/accretion rates, in $\mathrm{m} \mathrm{yr}^{-1}$ and by transect, for the period 1973-1986, 1986-2003 and 2003-2016. The archaeological areas/ sites are denoted.

and deteriorating important cultural deposits and structures, a finding that we corroborated during field surveys in late November 2016 (Fig. 9). Our reconstructed change rates in zone 3 are consistent with data from Khakzad et al. (2015a), who describe, between 1973 and 2012, total coastal retreat of around $8 \mathrm{~m}$ on the southern flank of Siraf's old coastal mosque $\left(52^{\circ} 20^{\prime} 06^{\prime \prime} 42 \mathrm{E} ; 27^{\circ} 40^{\prime} 02^{\prime \prime} 49 \mathrm{~N}\right)$. This rate is consistent with the value of $8.6 \mathrm{~m}$ (average $-0.2 \mathrm{~m} \mathrm{yr}^{-1}$ ) that we obtained in the same area for the period 1973 to 2016.

\subsection{Zone 4}

Zone 4 comprises 47 transects. This zone includes an ephemeral fluvial system. Total change from all geomorphic processes identified within zone 1 resulted in mean shoreline retreat of $-0.08 \mathrm{~m} \mathrm{yr}^{-1}$ for the total study period of 1973-2016. Between 1973 and 1987, the dominant geomorphological regime was accretionary with an average rate of $0.614 \mathrm{~m} \mathrm{yr}^{-1}$. By contrast, the periods 1987-2003 and 2003-2016 manifest the switch to an erosional regime with average erosion rates of $-0.427 \mathrm{~m} \mathrm{yr}^{-1}$ and $-0.442 \mathrm{~m} \mathrm{yr}^{-1}$. The strong erosional trend since 1987 appears to be linked to two factors: (1) sharp falls in sediment supply from the ephemeral fluvial system that exists in this area; and (2) construction of the fishing harbour of Siraf, that acts as a downdrift sediment trap and that blocks sediment transfer into zone 4 . For the periods $1987-2003$ and $2003-2016$, $77 \%$ and $70 \%$ of the 46 transects in this zone manifest erosion, respectively.

\subsection{Siraf's waterfront archaeology and the wider implications of coastal erosion}

Understanding the geomorphological processes encountered in particular landscape contexts is fundamental to developing effective heritage management strategies. In coastal environments in particular, the potential for the widespread and damaging erosion of archaeological remains is considerable. This is in part due to the increased erosion rates typically encountered in coastal areas, which has been exacerbated by global change and anthropogenic impacts on sediment supply. At Siraf, continued drought since the early 2000s has severely affected sediment supply to coastal areas (Figs. 10 and 11) leading to extensive erosion of the coastline during the past two decades. The area has recorded a stepwise decrease in total precipitation, with an annual average of $196.53 \mathrm{~mm} \mathrm{yr}^{-1}$ between 1973 and 1986, $187.97 \mathrm{~mm} \mathrm{yr}^{-1}$ between 1986 and 2003 and $174.24 \mathrm{~mm} \mathrm{yr}^{-1}$ between 2003 and 2014. This trend is mirrored by the regional watercourses of Mand and Hilla which, although not in direct vicinity of Siraf, are representative of the fluvial systems in the Busher province. We note a threefold decrease in discharge rates between 1970-1986 and 2003-2011, with significant impacts on sediment delivery to the region's coasts. The city's

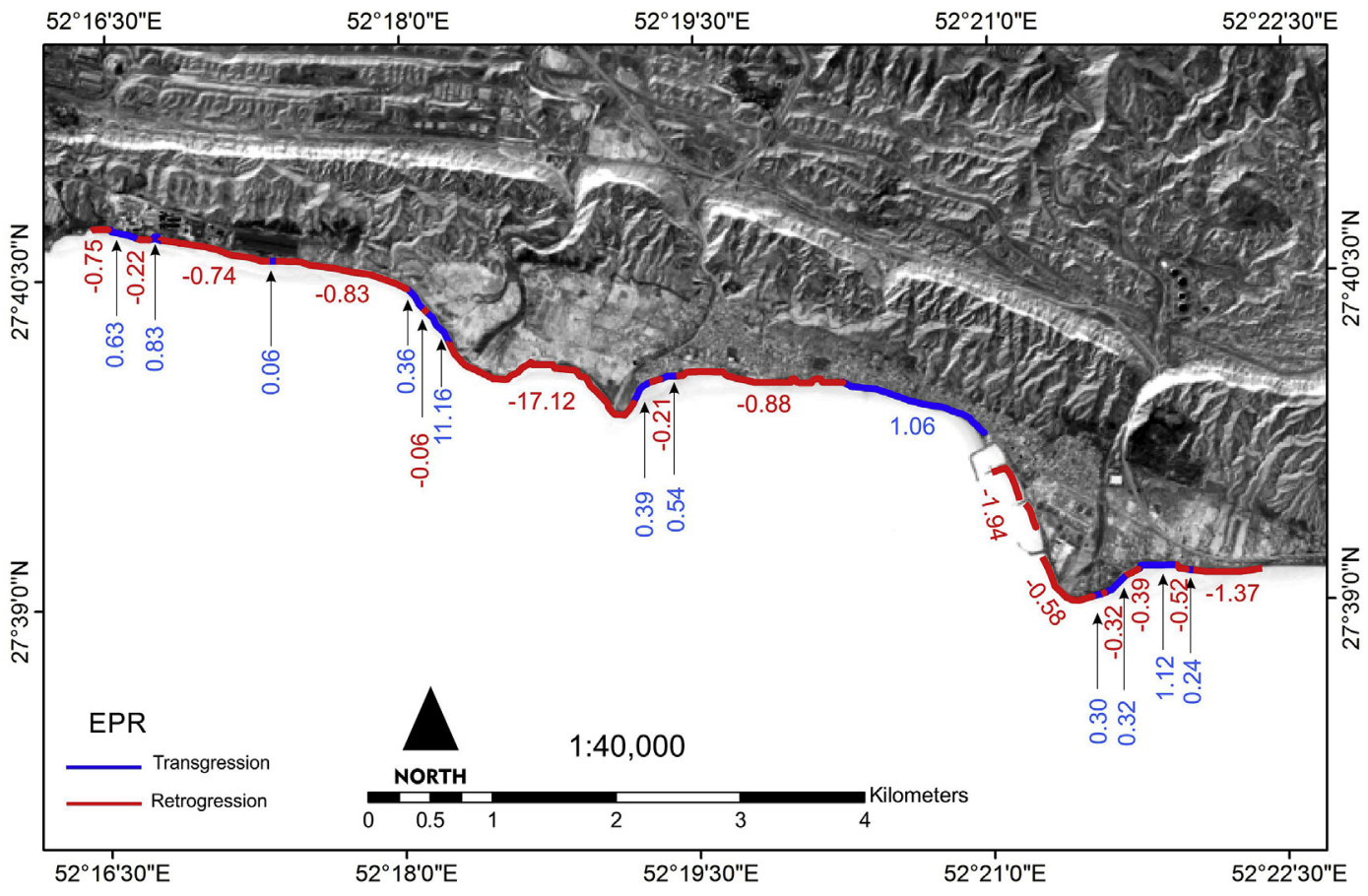

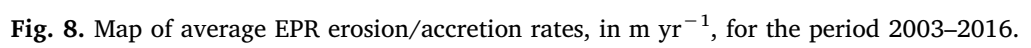



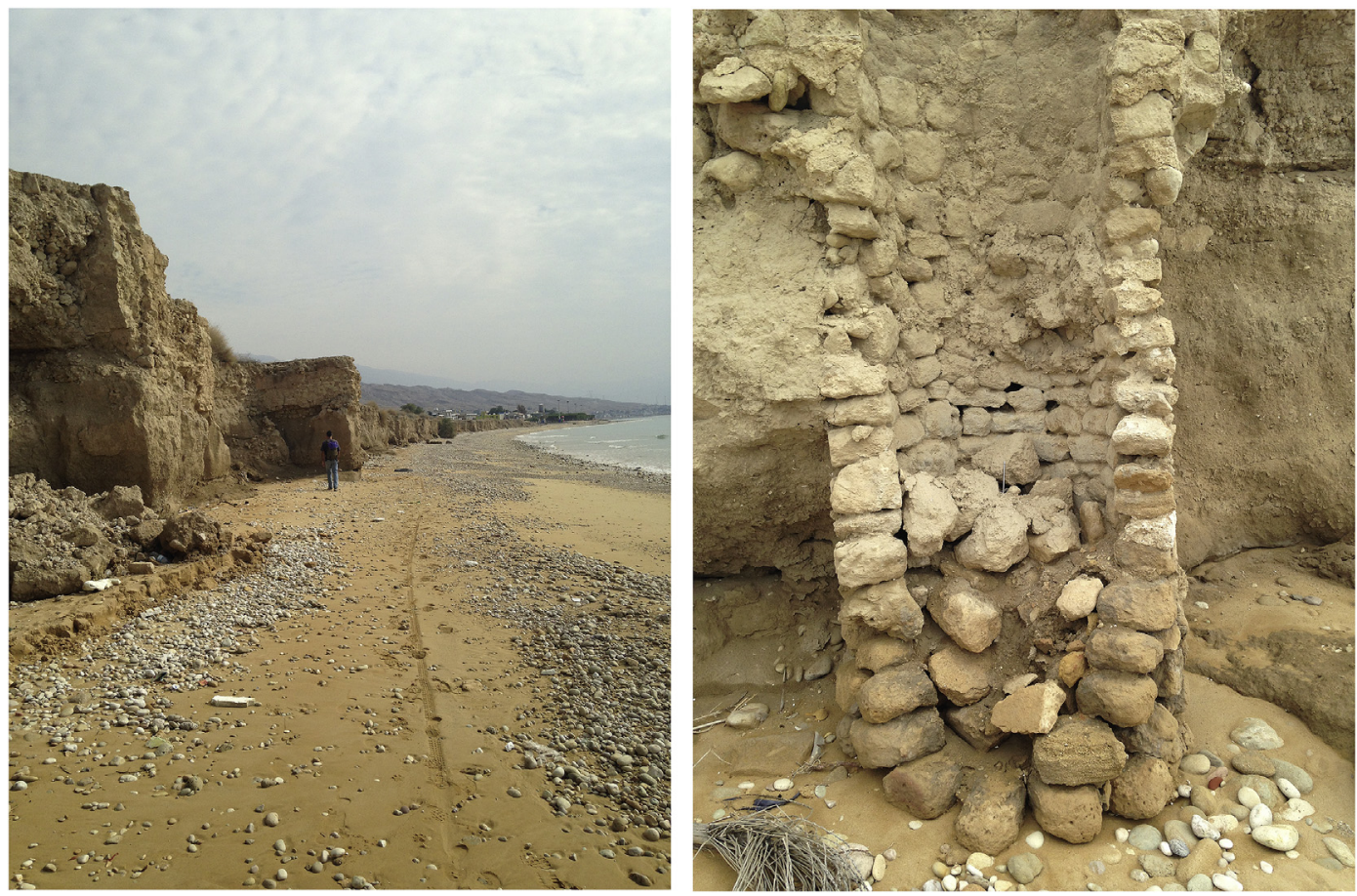

Fig. 9. Photographs of the coastal erosion at the base of Siraf's old city walls (Group 3 transects).

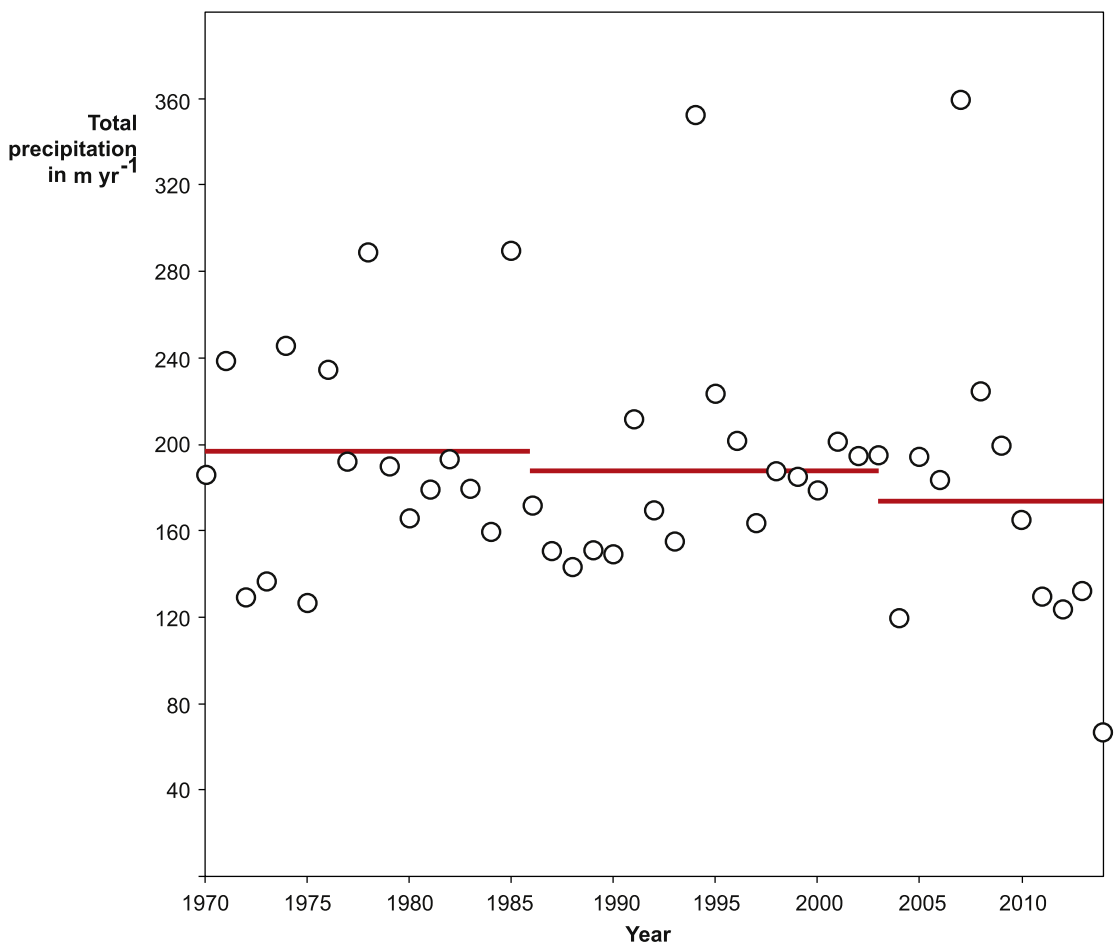

Fig. 10. Annual total precipitation for the Siraf area (data from http://climate.geog.udel.edu/ climate/html_pages/ Global2014/README.GlobalTsP2014.html). The red lines denote annual averages for the periods 1970-1986, 1986-2003 and 2003-2014. (For interpretation of the references to colour in this figure legend, the reader is referred to the Web version of this article.)

waterfront archaeology is particularly exposed and at danger due to the highly erodible nature of its deposits (Fig. 12). The erosion of Siraf's coastal archaeology is an ongoing legacy problem that must be urgently addressed by local, national and international stakeholders, including urban and coastal planners, heritage managers, archaeologists and geomorphologists. To effectively combat the problem, we suggest continued and close monitoring of the ongoing erosion.

\section{Conclusions}

Analyses of Landsat images have provided an effective methodology for monitoring the why, when and where of coastal change at Siraf. $70 \%$ of the coastline is presently undergoing erosion with widespread implications for the city's important archaeological deposits and upstanding structural remains. Although further work is required to assess when this erosion takes place, we suggest that low-magnitude erosion plays an important role in destabilizing surface deposits, with the most significant occurring during high-magnitude storm events. At present, 


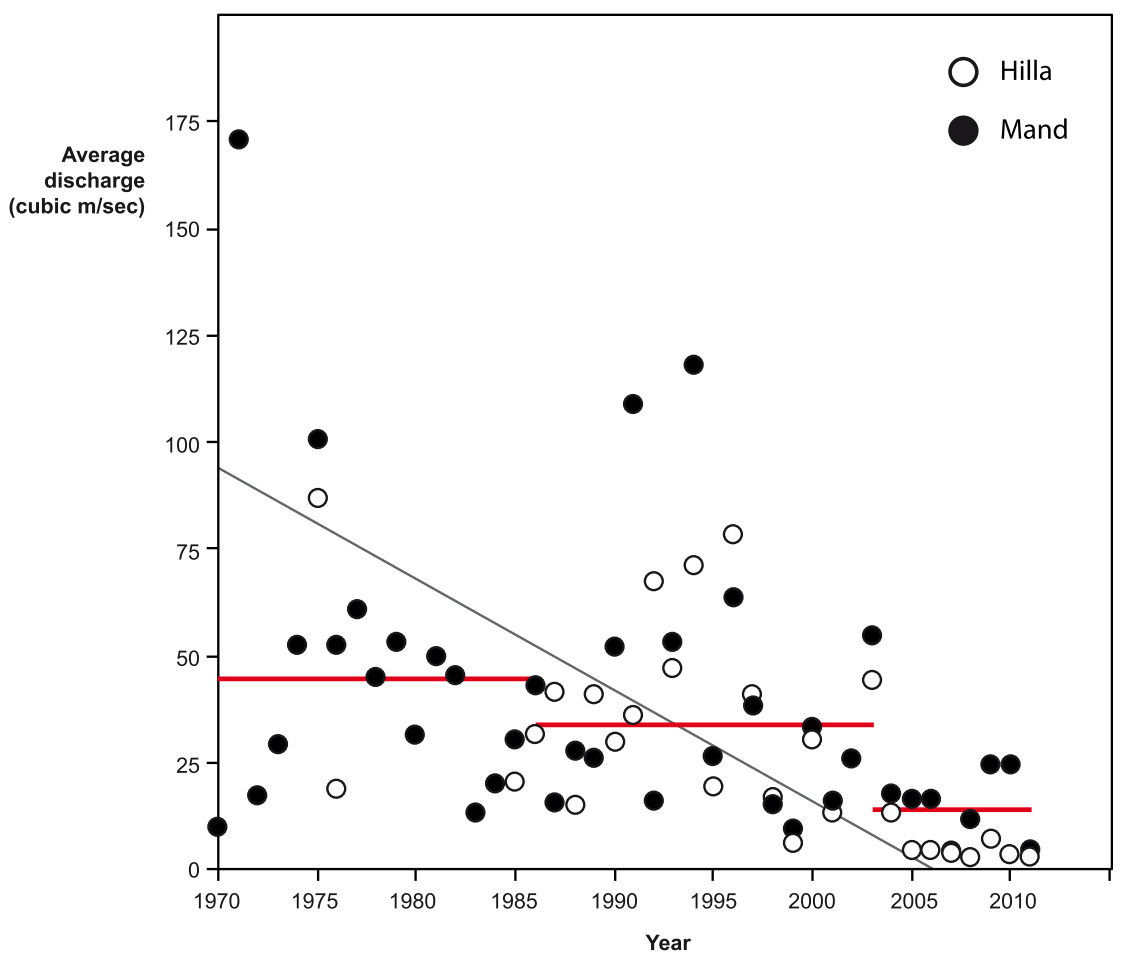

Fig. 11. Average annual discharge of the rivers Mand and Hilla on the Persian Gulf (for the linear correlation, $\mathrm{r}=-0.44)$. The red lines denote annual averages for the periods 1970-1986, 1986-2003 and 2003-2011. (For interpretation of the references to colour in this figure legend, the reader is referred to the Web version of this article.)

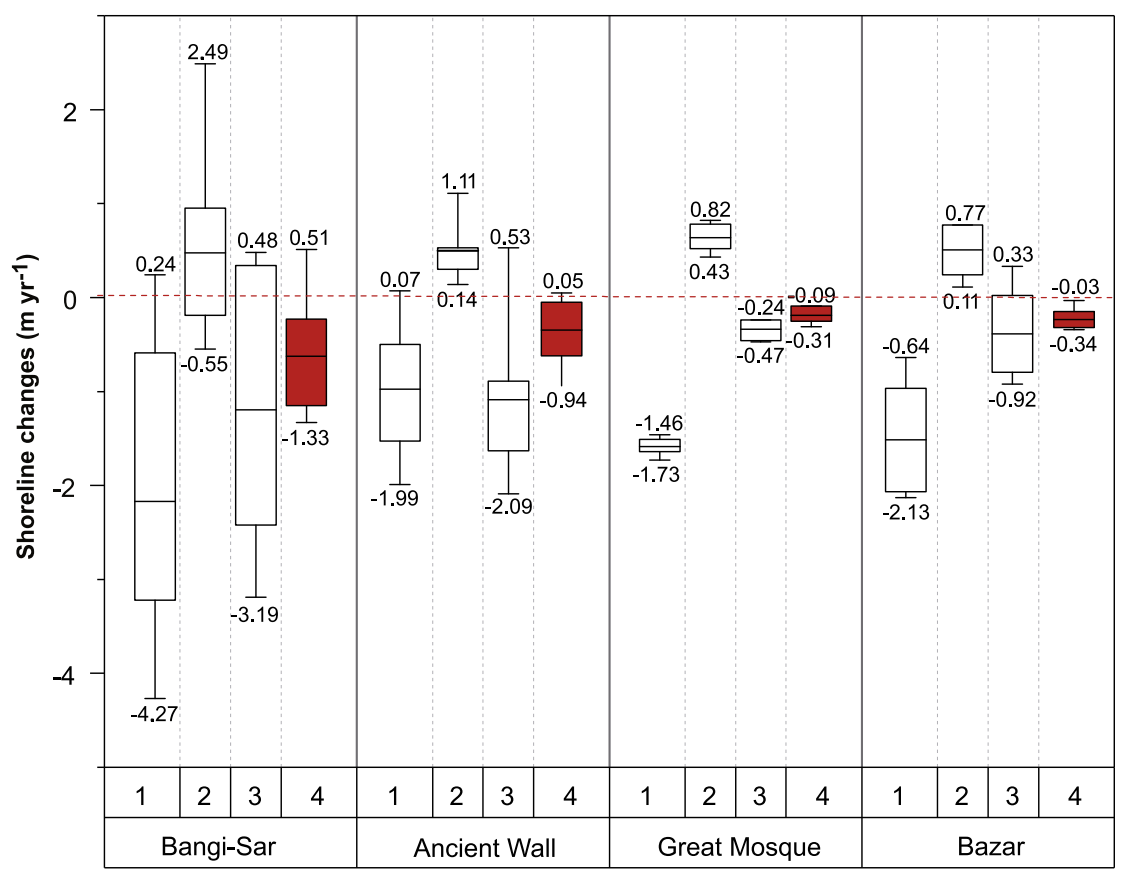

Fig. 12. Box plots of shoreline changes rates at important archaeological sites for the different time periods (1: 1973-1987; 2: 1987-2003; 3: 2003-2016 and 4: 1987-2016).

the resolution of our present data does not allow us to effectively probe this aspect of the coastal erosion, and a local monitoring program would be advantageous.

In sum, our research suggests that a well-defined management and protection plan is urgently required for Siraf. Our data and mapping of the erosion now provide a baseline of geographic information with which to develop an appropriate and targeted management plan, which must include national and international stakeholders. This research has emphasized the need for interdisciplinary approaches to the research and management Siraf's waterfront archaeology. There is an urgent need for appropriate mitigation strategies to be designed and implemented in order to combat this rapid coastal erosion, which is threatening a site of national and international importance.

\section{Acknowledgements}

This work was supported by the Center of International Scientific Studies and Collaborations (CISSC), Iran National Science Foundation (INSF grant number 94-44915), the French Embassy in Iran, Campus France (PHC GUNDISHAPUR 2016-2017, project number 35630QH) and Labex OT-Med (ANR-11-LABX-0061). 


\section{Appendix A. Supplementary data}

Supplementary data to this article can be found online at https:// doi.org/10.1016/j.apgeog.2018.10.008.

\section{References}

Ahmad, Y. (2006). The scope and definitions of heritage: From tangible to intangible. International Journal of Heritage Studies, 12, 292-300.

Andreou, G. M., Opitz, R., Manning, S. W., Fisher, K. D., Sewell, D. A., Georgiou, A., et al. (2017). Integrated methods for understanding and monitoring the loss of coastal archaeological sites: The case of Tochni-Lakkia, south-central Cyprus. Journal of Archaeological Science: Reports, 12, 197-208.

Anthony, E. J., Marriner, N., \& Morhange, C. (2014). Human influence and the changing geomorphology of Mediterranean deltas and coasts over the last 6000 years: From progradation to destruction phase? Earth-Science Reviews, 139, 336-361.

Appeaning Addo, K. A., Walkden, M., \& Mills, J. P. (2008). Detection, measurement and prediction of shoreline recession in Accra, Ghana. ISPRS Journal of Photogrammetry and Remote Sensing, 63, 543-558.

Beck, A., Philip, G., Abdulkarim, M., \& Donoghue, D. (2007). Evaluation of Corona and Ikonos high resolution satellite imagery for archaeological prospection in western Syria. Antiquity, 81(311), 161-175.

Boak, E. H., \& Turner, I. L. (2005). Shoreline definition and detection: a review. Journal of Coastal Research, 21, 688-703.

Brunel, C., \& Sabatier, F. (2009). Potential influence of sea-level rise in controlling shoreline position on the French Mediterranean Coast. Geomorphology, 107, 47-57.

Dawson, T. (Ed.). (2005). Coastal archaeology and erosion in Scotland. Edinburgh: Historic Scotland.

Deroin, J.-P., Téreygeol, F., \& Heckes, J. (2011). Evaluation of very high to medium resolution multispectral satellite imagery for geoarchaeology in arid regions - case study from Jabali, Yemen. Journal of Archaeological Science, 38(1), 101-114.

Dromgoole, S. (Ed.). (2006). The protection of the underwater cultural heritage: National perspectives in light of the UNESCO convention 2001. Brill.

El Banna, M., \& Frihy, O. E. (2009). Human-induced changes in the geomorphology of the northeastern coast of the Nile delta, Egypt. Geomorphology, 107, 72-78.

Erlandson, J. M. (2008). Racing a rising tide: Global warming, rising seas, and the erosion of human history. Journal of Island and Coastal Archaeology, 3(2), 167-169.

Erlandson, J. M. (2012). As the world warms: Rising seas, coastal archaeology and the erosion of maritime history. Journal of Coastal Conservation, 16, 137-142.

Ford, M. R., \& Kench, P. S. (2015). Multi-decadal shoreline changes in response to sea level rise in the Marshall Islands. Anthropocene, 11, 14-24.

Franco, L. (1996). Ancient Mediterranean harbours: A heritage to preserve. Ocean \& Coastal Management, 30, 115-151.

García-Rubio, G., Huntley, D., \& Russell, P. (2015). Evaluating shoreline identification using optical satellite images. Marine Geology, 359, 96-105.

Khakzad, S., Pieters, M., \& Van Balen, K. (2015b). Coastal cultural heritage: A resource to be included in integrated coastal zone management. Ocean \& Coastal Management, 2015, 1-19.

Khakzad, S., Trakadas, A., Harpster, M., \& Wittig, N. (2015a). Maritime aspects of medieval Siraf, Iran: A pilot project for the investigation of coastal and underwater archaeological remains. The International Journal of Nautical Archaeology, 44(2), 258-276.

Klemas, V. (2011). Remote sensing techniques for studying coastal ecosystems: an overview. Journal of Coastal Research, 27, 2-17.

Lasaponara, R., \& Masini, N. (2011). Satellite remote sensing in archaeology: Past, present and future perspectives. Journal of Archaeological Science, 38(9), 1995-2002.

Manca, E., Pascucci, V., Deluca, M., Cossu, A., \& Andreucci, S. (2013). Shoreline evolution related to coastal development of a managed beach in Alghero, Sardinia, Italy. Ocean \& Coastal Management, 85, 65-76.

Marriner, N., \& Morhange, C. (2005). Under the city centre, the ancient harbour. Tyre and Sidon: Heritages to preserve. Journal of Cultural Heritage, 6, 183-189.

Miller, H. M., Sexton, N. R., Koontz, L., Loomis, J., Koontz, S. R., \& Hermans, C. (2011). The users, uses, and value of Landsat and other moderate-resolution satellite imagery in the United States - executive report U.S. Geological Survey Open-File Report 2011-1031.

Moore, L. J. (2000). Shoreline mapping techniques. Journal of Coastal Research, 16, $111-124$.

Morton, R. A., Miller, T. L., \& Moore, L. J. (2004). National assessment of shoreline change, part 1: Historical shoreline changes and associated coastal land loss along the U.S. Gulf of Mexico U.S. Geological Survey Open-file report 2004-1043.

Mourtzas, N. D., \& Marinos, P. G. (1994). Upper Holocene sea-level changes: Paleogeographic evolution and its impact on coastal archaeological sites and monuments. Environmental Geology, 23, 1-13.

Pardo-Pascual, J. E., Almonacid-Caballer, J., Ruiz, L. A., \& Palomar-Vázquez, J. (2012). Automatic extraction of shorelines from Landsat TM and ETM + multi-temporal images with subpixel precision. Remote Sensing of Environment, 123, 1-11.

Pashazanous, H. R., Montazer Zohouri, M., \& Ahmadi, T. (2014). Sea trade between Iran and China in the Persian Gulf based on the excavations of Siraf city. Indian Journal of Economics and Development, 2, 6-13.

Ricks, T. M. (1970). Persian Gulf Seafaring and East Africa: Ninth-twelfth centuries. African Historical Studies, 3, 339-357.

Robinson, M. H., Alexander, C. R., Jackson, C. W., McCabe, C. P., \& Crass, D. (2010). Threatened archaeological, historic, and cultural resources of the Georgia coast: Identification, prioritization and management using GIS technology. Geoarchaeology, 25, 312-326.

Rousseeuw, P. J., \& Leroy, A. M. (2005). Robust regression and outlier detection, Vol. 589. John Wiley \& Sons.

Ruddick, B., Anis, A., \& Thompson, K. (2000). Maximum likelihood spectral fitting: The Batchelor spectrum. Journal of Atmospheric and Oceanic Technology, 17, 1541-1555.

Ryu, J.-H., Won, J.-S., \& Min, K. D. (2002). Waterline extraction from Landsat TM data in a tidal flat: a case study in Gosmo Bay, Korea. Remote Sensing of Environment, 83, 442-456.

Singh, O. P. (2002). Interannual variability and predictability of sea level along the Indian coast. Theoretical and Applied Climatology, 72, 11-28.

Stewart, D. J. (1999). Formation processes affecting submerged archaeological sites: An overview. Geoarchaeology, 14, 565-587.

Syvitski, J. P. M., Vörösmaty, C. J., Kettner, A. J., \& Green, P. (2005). Impacts of humans on the flux of terrestrial sediments to the global coastal ocean. Science, 308, 376-380.

Tulbure, M. G., Broich, M., Stehman, S. V., \& Kommareddy, A. (2016). Surface water extent dynamics from three decades of seasonally continuous Landsat time series at subcontinental scale in a semi-arid region. Remote Sensing of Environment, 178, 142-157.

Vanhellemont, Q., \& Ruddick, K. (2014). Turbid wakes associated with offshore wind turbines observed with Landsat 8. Remote Sensing of Environment, 145, 105-115.

Whitehouse, D. (1980). Siraf III. The Congregational Mosque and other mosques from the ninth to the twelfth centuries. (London).

Whitehouse, D. (2009). Siraf, history, topography and environment. (Oxford).

Whitehouse, D., \& Williamson, A. (1973). Sasanian Maritime Trade. Iran, 11, 29-49.

Wilkinson, T. J. (1974). Agricultural decline in the Siraf region, Iran. Paleorient, 2, 123-132.

Wilkinson, K., Tyler, A., Davidson, D., \& Grieve, I. (2006). Quantifying the threat to archaeological sites from the erosion of cultivated soil. Antiquity, 80, 658-670.

Yamazaki, D., Trigg, M. A., \& Ikeshima, D. (2015). Development of a global 90m water body map using multi-temporal Landsat images. Remote Sensing of Environment, 171, 337-351.

$\mathrm{Ya}^{-} \mathrm{qu}^{-}$, t (1955). Mu'jam al-Buldan. Vol. 57 (Beirut). 